\title{
PAUL DAVIDSON
}

Rutgers-The State University

LAURENCE H. FALK

Rutgers-The State University

HOESUNG LEE

Rutgers-The State University

\section{Oil: Its Time Allocation and Project Independence}

IN 1973, THE onset of an energy crisis in a world that for a century had been plagued by potential oversupply of fossil fuels at existing market prices caught many knowledgeable observers by surprise. The energy shortage immediately generated a search for a scapegoat or a rational explanation of the predicament of the highly developed, capitalist economies, heavily based on energy resources, of the United States, Western Europe, and Japan.

According to Leonard Silk, the mammoth multinational energy companies, afflicted by the same "pea-sized brain" that proved fatal to the dinosaurs, either caused or exacerbated the problem. His analysis depicted corporate mastodons as relentlessly pursuing the goal of profit maximization; but it concluded that since "economics is not everything," society cannot be at the mercy "of corporations that have no other purpose than 
profit-maximization, however legitimate and useful that objective may be in a limited context."1

Yet orthodox economic theory has taught that, given the right background assumptions, businessmen's single-minded pursuit of profit opportunities, tempered by competition and the absence of externalities, would result in an efficient and optimum allocation of resources and the maximization of the welfare of the community. Thus, contrary to Silk's condemnation, executives of multinational energy companies should not be pilloried for failing to meet the needs of any one selfish nation, for in their pursuit of profit maximization, they are unwittingly maximizing the economic welfare of mankind. Responding to comments on the lack of competition at various stages of the vertically integrated oil industry, some students of the industry claim that the international supply of crude oil is "the same as what might be expected to arise from the operation of the law of comparative costs in a freely competitive international market."' After all, the consumer seemed to be plentifully, and cheaply, supplied.

Even now that more economists are willing to acknowledge how noncompetitive the oil-resource market is, many continue to envision the problem of depletable fossil fuels in terms of determining the "optimal social management of a stock of a nonrenewable but essential resource." 3 An immediate consequence of this way of conceptualizing the problem is to analyze the existing structure of the resource market to see whether it provides "proper" price allocative guidelines. If it can be proven that the market "fails," then it follows (for those who use this approach) that the role of the economist is to design policies to improve market performance and bring it closer to the competitive ideal. In other words, the first instinct of many economists in this field is to leave the decision as to the time rate of exploitation of exhaustible resources to the invisible hand, unless a market failure can be demonstrated and a corrective policy can be developed.

1. Leonard Silk, "Multınational Morals," New York Times, March 5, 1974.

2. J. E. Hartshorn, Politics and World Oil Economics: An Account of the International Oil Industry in Its Political Environment (Praeger, 1962), p. 340. Even in 1974 studies have been produced to show that "prices paid by consumers for petroleum products reflect the actual costs of suppliers and are not 'padded' by excess profits. The competitive process has held industry profits down." See Edward J. Mitchell, U.S. Energy Policy: A Primer (Washington: American Enterprise Institute, 1974), p. 103.

3. Robert M. Solow, "The Economics of Resources or the Resources of Economics," in American Economic Association, Papers and Proceedings of the Eighty-sixth Annual Meeting, 1973 (American Economic Review, Vol. 64, May 1974), p. 2. 
In the first section of this paper we deal with two related issues: First, can market prices, even in a competitive environment, provide adequate guidelines for approaching an efficient and optimal rate of utilization of exhaustible resources? Second, in a world of conglomerate energy companies, does rationality of entrepreneurial policies imply anticompetitive and antisocial behavior that redistributes income from consumers to producers and owners of resource-bearing property? Some policy implications inevitably follow from this analysis.

The second section presents our estimates of the market price for crude oil required to achieve the stated goal of Project Independence: selfsufficiency by $1980 .{ }^{4}$ Since the first section attempts to demonstrate that for policy purposes economists who seek to determine the efficiency of any given time rate of exploitation of oil properties only waste their own resources, it follows that no one can tell whether Project Independence is on a socially optimal management path-that is, whether self-sufficiency in 1980 will maximize the sum of discounted consumer and producer surpluses. But once self-sufficiency is established as a desirable goal by society's decisionmakers, economists can examine alternative paths to that objective and their implications for prices, income distribution, and production flows. ${ }^{5}$

In the second section we have estimated the 1980 market-clearing, longrun price necessary to achieve self-sufficiency, given the historical supply and demand elasticities for petroleum. A sensitivity analysis of this estimate to variations in supply and demand elasticities is also presented.

\section{Market Prices and Exhaustible Resources}

In a recent paper William Nordhaus not only succinctly summarized the foundation for the orthodox economic belief in the desirability of a laissezfaire approach to exhaustible-resource pricing, but also attempted to simu-

4. "The Energy Emergency," The President's Address to the Nation, November 7, 1973, in Weekly Compilation of Presidential Documents, Vol. 9 (November 12, 1973), pp. 1312-22.

5. It is our belief that economists should acknowledge their role as "soft" scientists providing advice to policymakers regarding "hard" decisions. Moreover, even as soft scientists we do not hesitate to suggest that policy should aim at (1) protecting consumers from paying more than the normal supply price for essential goods and services, and (2) encouraging "Enterprise" and preventing "Speculation" from dominating economic activities. 
late how such a pricing system would tend to allocate, over the next 200 years, the known recoverable energy resources of the world.

The theoretical foundation for Nordhaus' analysis relies on the theory of general economic equilibrium. It assumes

consumers with initial resources and given preferences, and producers operating with well-defined technical relations. . . . [It] can embrace many time periods and uncertainty about the exact demand or supply conditions; but it assumes convex production and preference sets, and that markets exist for all goods, services, and contingencies. ... [including] futures markets for, say, petroleum and coal in the year 2000; and ... insurance markets for such contingencies as the failure of breeder processes to become economically viable. Also, all the costs and benefits of a particular process of production must be internalized to the decision maker. Under the above conditions a market system will have a general equilibrium of prices and quantities.... [T] he equilibrium will be efficient in the sense that there is no way of improving the lot of one consumer without worsening the lot of another. Expressed differently, the prices are appropriate indicators of social scarcity. ...6

Although many economists subscribe to the general-equilibrium notion that market prices can allocate energy resources efficiently over time, others such as F. H. Hahn have noted that the theory of general economic equilibrium can only be used as an argument against someone

... who maintains that we need not worry about exhaustible resources because they will always have prices which ensure their "proper" use. . . A quick way of disposing with the claim is to note that an Arrow-Debreu equilibrium must be an assumption he is making for the economy and then to show why the economy cannot be in this state. The argument will here turn on the absence of futures markets and contingent futures markets and on the inadequate treatment of time and uncertainty.... This negative rôle of Arrow-Debreu equilibrium I consider almost to be sufficient justification for it, since practical men and ill-trained theorists everywhere in the world do not understand what they are claiming... when they claim a beneficent and coherent rôle for the invisible hand....

... [Since] we know that these [futures] markets are in fact very scarce [and]... some contingent markets could logically not exist ... we can easily refute propositions [like these] on exhaustible resources.... Moreover one can locate precisely where the argument goes wrong. ${ }^{7}$

A "proper" use of any exhaustible resource requires entrepreneurial decisions on the time rate of its production. The market price system can

6. William D. Nordhaus, "The Allocation of Energy Resources," Brookings Papers on Economic Activity ( $3: 1973)$, pp. 530-31. Hereafter this document will be referred to as $B P E A$, followed by the date.

7. Frank H. Hahn, On the Notion of Equilibrium in Economics (London: Cambridge University Press, 1973), pp. 14-16 (emphasis supplied). 
provide guidance on an optimal resource allocation over time only under the following conditions:

1. Well-organized forward markets exist for each date in the future.

2. Consumers know with actuarial certainty all their needs of energy resources at each date.

3. Consumers are able and willing to exercise all these future demands by currently entering into forward contracts for each date.

4. Entrepreneurs know with actuarial certainty the costs of production associated with production flows for each date.

5. Sellers can choose between an immediate contract at today's market price and a forward contract at the market price associated with any future delivery date (over 73,000 in the Nordhaus model).

6. Entrepreneurs know with actuarial certainty the course of future interest rates.

7. The social rate of discount equals the rate at which entrepreneurs discount future earnings and costs. ${ }^{8}$

8. No false trading occurs-that is, no production or exchange ever takes place at nonequilibrium prices. ${ }^{9}$

If all these conditions are met, then in a competitive environment, market prices can be shown to be an efficient or socially optimal way to allocate energy resources over time, in the sense of maximizing the sum of discounted consumer and producer surpluses.

Since for any particular property, the fossil fuels in the ground are a fixed inventory (or exhaustible resource), the more used today, ceteris paribus, the less will be available for future delivery. Consequently, a

8. This condition can hold only if monetary and fiscal policy are so precisely applied that they eliminate any divergence between the natural rate of interest and the market rate of interest. See Kenneth J. Arrow, "Discounting and Public Investment Criteria," in Allen V. Kneese and Stephen C. Smith (eds.), Water Research (Johns Hopkins Press for Resources for the Future, 1966), pp. 13-32.

9. The absence of false trading is an esoteric but essential condition for the beneficence of the invisible hand. In the real world of uncertainty, however, false trades are inevitable and hence those who look to market prices to allocate energy resources properly over time are pursuing a will-o'-the-wisp.

Currently, general-equilibrium theorists utilize the assumption of a complete set of futures markets for all contingent commodities to eliminate uncertainty and false trades from their models. This is merely a logical dodge for it requires that contracts for all contingent commodities be entered into at market-clearing prices at the initial date-that is, all possible human agreements for every contingency involve prices that reconcile all plans and expectations before any production and exchange occurs and no additional contracts can be entered into for the rest of time. 
rational entrepreneur will compare the present value of expected profits for a forward contract sale at each possible future date with the profitability of selling that amount today. If profit-maximizing entrepreneurs are to produce for current sale, current marginal revenue must be expected to cover not only current marginal factor costs associated with that barrel of oil but also the user costs inherent in all depletable resources-namely, the highest present value of marginal future profits given up by producing that barrel of oil currently rather than in the future. ${ }^{10}$ Thus, for example, Nordhaus attempts to simulate the allocation arising from a complete set of spot and forward market prices assuming that (1) the 1970 information about supply availability and costs was accurate and relevant for each time period for the next two centuries, and (2) energy demands over the foreseeable future could be projected from the 1929-68 historical growth rates (ignoring price elasticity effects). ${ }^{11}$

As Nordhaus recognizes, ${ }^{12}$ forward markets for most commodities do not exist and, as Hahn has noted, they cannot logically exist in the real world where the future is yet to be created. Arrow has attributed the failure

10. For a complete discussion of user costs and petroleum production, see $\mathrm{Pau}^{\mathrm{l}}$ Davidson, "Public Policy Problems of the Domestic Crude Oil Industry," American Economic Review, Vol. 53 (March 1963), pp. 85-108; also see Robert G. Kuller and Ronald G. Cummings, "An Economic Model of Production and Investment for Petroleum Reservoirs," American Economic Review, Vol. 64 (March 1974), pp. 66-79.

As Champernowne has indicated, Keynes borrowed the term "user cost" from Marshall, but was the first to develop the concept and apply it to the question of intertemporal production from depletable properties. See D. G. Champernowne, "Expectations and the Links Between the Economic Present and Future," in Robert Lekachman (ed.), Keynes' General Theory: Reports of Three Decades (St. Martin's, 1964), p. 177; and John Maynard Keynes, The General Theory of Employment, Interest and Money (Harcourt, Brace, 1936), pp. 66-73. Since then many other authors have refined the usercost concept to analyze entrepreneurial decisions about the timing of production in the short run. See, for example, Joe S. Bain, "Depression Pricing and the Depreciation Function," Quarterly Journal of Economics, Vol. 51 (August 1937), pp. 705-15; Alfred C. Neal, Industrial Concentration and Price Inflexibility (American Council on Public Affairs, 1942), pp. 58-61; Sidney Weintraub, Price Theory (Pitman, 1949), pp. 378-81; A. D. Scott, "Notes on User Cost," Economic Journal, Vol. 63 (June 1953), pp. 368-84; Anthony D. Scott, "The Theory of the Mine Under Conditions of Certainty," in Mason Gaffney (ed.), Extractive Resources and Taxation (University of Wisconsin Press, 1967), pp. 34-41; M. Mason Gaffney, "Soil Depletion and Land Rent," Natural Resources Journal, Vol. 4 (January 1965), pp. 537-57; and M. A. Adelman, The World Petroleum Market (Johns Hopkins University Press for Resources for the Future, 1972), p. 40.

11. Nordhaus, "Allocation of Energy Resources," pp. 537-41.

12. Ibid., p. 534. 
of real-world economies to develop forward markets in most goods ${ }^{13}$ to the costliness of enforcing forward contracts to dates far in the future, and the unwillingness of buyers and sellers to make forward contractual production and purchase commitments. ${ }^{14}$ Even if one is willing to overlook what Arrow terms the "failure of markets for future goods" in attempting to model an "efficient" time path that might apply in the presence of futures markets (as Nordhaus does), the necessary assumption that no false trading occurs dooms the search for an efficient allocative mechanism that relies on market prices. If false trading occurs, the parameters of the economy change and it is extremely unlikely that the original set of equilibrium spot and forward prices over time will continue to provide an efficient solution-or that any other set can.

In the past, general-equilibrium theorists such as Hicks have avoided the devastating conclusion that economists cannot say anything meaningful about efficient resource use over time by merely assuming that false trading is negligible. Hicks justified this assumption by shortening the time horizon-to less than a day if necessary..$^{15}$ But, then, those who advocate a market-price solution for allocating exhaustible fossil fuels over years, decades, or even centuries cannot use general-equilibrium theory to justify their position.

Many economists ignore these formidable issues by developing models for a world of certainty with a specified time horizon. Other economists merely assert that resource markets in the real world normally behave much as they would in a world of certainty, and that therefore general-equilibrium models are a useful "parable" for analyzing the efficient time rate of exploitation of exhaustible resources. For example, Solow states: “.... in tranquil conditions, resource markets are likely to track their equilibrium paths moderately well, or at least not likely to rush away from them....

13. Kenneth J. Arrow, "Limited Knowledge and Economic Analysis," American Economic Review, Vol. 64 (March 1974), p. 8.

14. In fact, however, long-term (often perpetual) leases are the rule for properties that bear natural resources.

But many of those who will be buyers in the future may at any given time be yet unborn; or, if already alive, too young to enter into the contracts necessary to convert future wants into demand, or uncertain how much energy resources they will need in the future. Under these circumstances a free market system could not allocate energy resources over decades or centuries to achieve Pareto efficiency even if a complete set of futures markets for all contingent commodities existed.

15. J. R. Hicks, Value and Capital: An Inquiry into Some Fundamental Principles of Economic Theory (2d ed., Oxford University Press, 1946), p. 129. 
[Of course] resource markets may be rather vulnerable to surprises. . . It may be quite a while before the transvaluation of values ... settles down under the control of sober future prospects." 16 This belief in "tranquil conditions" and the ultimate dominance of "sober" minds in the long run-in short, the stability of expectations-is the bedrock of the neoclassical view that the competitive market may yet, with sufficient empirical study and analysis, yield the secret of determining the socially optimal exploitation of exhaustible resources over time.

One of the more ingenious attempts at developing such a scenario for energy-resource use over time has been Nordhaus' monumental study. Nordhaus' work has been described as an analysis of "... how energy requirements will be met in the long run, ... [and of] the pattern of uses and prices of various types of energy that would emerge through time in a free competitive market. While he acknowledges some of the ways in which actual prices may differ from those generated by his model, he regards his general outline of resource utilization and price changes as helpful indicators of how the future of energy use is likely to unfold." 17 Nordhaus notes that in his model "the price system is ex ante efficient as long as a complete set of futures markets exists." $18 \mathrm{He}$ recognizes that the absence of these markets might create "serious problems," but he argues that "an estimate of whether current usage is too fast or too slow cannot be made a priori; it can emerge only from a carefully constructed econometric and engineering model of the economy." 19

Here we must disagree. ${ }^{20}$ As Shackle has pointed out, "the existence of 'futures' markets is a mere technical gloss on the essential situation," since speculators enter into contracts in futures markets because they disagree with the market's valuation of the future. Hence when the future

16. Solow, "Economics of Resources," p. 7. In correspondence regarding this paper, Solow has indicated that he accepts the view that an optimal strategy is a will-o'-the-wisp. Nevertheless, he maintains that it is possible to judge that some intertemporal allocations are better or more efficient than others with a high degree of probability.

17. Arthur M. Okun and George L. Perry, "Editors' Introduction and Summary," $B P E A$ (3:1973), p. 516.

18. Nordhaus, "Allocation of Energy Resources," p. 534.

19. Ibid., p. 537.

20. This is not to deny Nordhaus' conclusion about the immense availability of fossil fuels! And Nordhaus has described at least one possible scenario for the future. But this scenario has nothing to do with an optimal path in the real world.

21. George L. S. Shackle, Epistemics \& Economics: A Critique of Economic Doctrines (Cambridge, England: Cambridge University Press, 1972), p. 111. 
becomes the present, either the speculators or the market, or both, will have been in error and false trading (surprises) will have occurred. As long as the future is uncertain individual opinions about it are free to diverge from each other and from the pronouncements of any market. False transactions are an inevitable and ubiquitous phenomenon in the real world.

"[The] long run is a misleading guide to current affairs. In the long run we are all dead. Economists set themselves too easy, too useless a task if in tempestuous seasons they can only tell us that when the storm is long past the ocean is flat again." 22 Any attempt to provide policymakers with guidelines for solving real-world problems such as the energy crisis using assumptions of "a world of certainty" or "values under the control of sober future prospects" or "tranquil conditions," is, in our view, almost fruitless, and may be positively mischievous in that it may mislead practical men into claiming "a beneficent and coherent role for the invisible hand."

Because futures markets do not exist; because even if they did, false trading would occur in a world of uncertainty and change; and because estimates of future demands and costs are at best unreliable, it is impossible to specify any time rate of exploitation of resources that will be efficient or maximize the sum of discounted consumer and producer surpluses over any long period.

The a priori inability of market prices to provide any guideline for such allocation does not relieve producers from the responsibility of deciding the actual rate for exploiting these resources. Some economists, recognizing the hopelessness of specifying any policy for socially optimal resource management, have argued that "the mere statement of the problem ... serves to support a general disposition to leave these complicated calculations to the self-interest of businessmen in competitive markets," 23 in the delusive hope that the inevitable errors of many decisionmakers will tend to cancel out. In the early sixties, this view was not hard to accept, provided the government assured the existence of competitive markets, required field unitization, and removed certain favorable tax treatments. In the midst of a worldwide "energy crisis," leaving energy-resource production to businessmen's subjective estimates of user costs seems much less desir-

22. A Tract on Monetary Reform, Vol. IV, The Collected Writings of John Maynard Keynes (London: Macmillan, 1971 ed.), p. 65.

23. Melvin G. de Chazeau and Alfred E. Kahn, Integration and Competition in the Petroleum Industry (Yale University Press, 1959), p. 236. 
able. Current market conditions are likely to encourage all producers to expect rapid increases in prices (as a reflection of growing monopoly elements rather than of increasing social value), and such views will nurture monopoly growth with its concomitant redistribution of income from consumers to producers and ultimately to property owners in the form of economic rents. While some may disagree, we judge such a redistribution to be undesirable as well as unnecessary. Accordingly, we now believe that in the absence of omniscient producers or governments, the damage is likely to be minimized by the adoption of policies that eliminate positive user costs as an element in production decisions.

\section{USER COSTS IN THE ABSENCE OF FORWARD MARKETS}

In the absence of developed futures markets, producers' subjective expectations of the user costs inherent in all raw materials are major determining factors in the time rate of exploitation of energy resources. Given the time period, as long as the expected rate of increase in the difference between price and average factor costs is equal to the expected rate of interest, the marginal user cost is zero, and profit-maximizing managers will produce up to the point where current price equals the remaining marginal factor costs plus a markup or profit margin whose magnitude depends on the degree of monopoly the producers have in the marketplace. ${ }^{24}$ (If producers operated in a purely competitive market, price would simply equal marginal factor costs.)

If, however, for the future, price is expected to increase relative to production costs at an annual rate beyond the expected rate of interest, marginal user costs will be positive and current production will be reduced as producers withhold some energy resources to sell at a greater "discounted" profit at a future date. Finally, if prices are expected to decrease relative to costs (or to increase at less than the rate of interest), marginal user costs will be negative and current production will be higher than when marginal user costs are zero. Thus, in a world of uncertainty, we are left with a bootstrap theory of the time rate of exploitation of energy resources; current expectations of producers play the pivotal role in the absence of any "facts" about the future. Consequently, relative stability over time in prices and production in energy-resource markets requires that most pro-

24. The degree of monopoly power can be measured by $m=(P-M C) / P$, where $P$ is current price and $M C$ is marginal factor costs. 
ducers think that tomorrow will not be significantly different from today, although it can perhaps accommodate some divergency of views among producers.

If, however, most producers expect that the relation of prices to costs will change significantly in an uncertain future, energy-resource markets will be dominated by speculative activities. Since solid information about that future cannot exist, the result is bound to be detrimental to society. "Speculators may do no harm as bubbles on a steady stream of enterprise. But the position is serious when enterprise becomes the bubble on a whirlpool of speculation." 25

Until recently, state and federal governmental policies prevented rapid changes in wellhead prices in the United States. Market prorationing supported by the 1935 federal law, popularly known as the Connally Hot Oil Act, which prohibits interstate commerce in oil that was produced in violation of state prorationing laws, plus the operation of import quotas, effectively eliminated any positive user costs. At the same time, speculation in the international market was restrained by the ability of the "Seven Sisters" (the seven largest international oil-producing companies) to maintain an orderly market. However, most sellers of energy resources have been led to expect rapidly rising prices by the events of the early seventiesincluding the relaxation of market-demand prorationing; the growth of the power of the oil cartel, the Organisation of Petroleum Exporting Countries (OPEC), at the same time that import quotas were being removed; the unsettled politics of the Middle East. These events have stimulated speculative proclivities and consequently retarded current production of fossil fuels.

Current statistics from the U.S. Geological Survey (USGS) provide strong evidence of speculative withholding of oil production. Completed shut-in oil-producible zones ${ }^{26}$ offshore jumped from 953 in 1971 to 2,996 in 1972 and 3,054 in 1973, while active oil wells fell from 5,704 to 3,814 over this period, even though new wells continued to be completed at a rate of 300 to 400 per year. ${ }^{27}$ This jump in shut-ins from 14 percent of

25. Keynes, General Theory, p. 159.

26. A completed shut-in producible zone is an area in which a well has been drilled and has been determined by USGS to be capable of producing in paying quantities, but for which a suspension of production has been certified by USGS. There may be more than one producible zone associated with a single well.

27. U.S. Geological Survey, Conservation Division, Outer Continental Shelf Statistics (June 1974), pp. 29, 34-36. For a further discussion of the importance of the shut-in oil producible capacity, see the section, "A Final Caveat," below. 
producible zones in 1971 to over 44 percent in 1972 does suggest an explicit decision by producers to restrict available production flows. Moreover, since producers can restrict oil production not only by a complete shut-in of oil wells but also by reducing flows from producing wells, shutting in associated gas wells, and slowing down drilling activity on wells nearing completion, and since the shut-in statistics cover only offshore completed oil-producible zones, speculative withholding may be significantly greater than these statistics suggest. ${ }^{28}$

If this speculation is unwarranted-that is, if producers' expectations do not properly reflect the relative valuation of buyers and the costs of producing energy resources for future use vis-à-vis their present use (and in an uncertain world there is no reason why they can or should)-then governments must act to prevent such profit-maximizing speculative activity from harming today's society. Stability in today's energy markets may be a humbler goal than the efficient allocation of energy resources over the long run but, at least, it is achievable.

In the current "energy crisis" two major factors have spurred speculative excesses in the energy market. These are the growth of the monopoly power of the OPEC cartel, and the development of conglomerate energy companies.

\section{OPEC AND USER COSTS}

OPEC oil has always been sold by producers who had not only significant monopoly power in product markets, but also, in the past, monopsony power in the market for oil-bearing properties. The existence of large monopoly rents, as well as the possible withholding of diminishing-return rents by monopsonist producers on properties in the OPEC nations, has now encouraged the host nations to attempt to capture some of these rents

28. A recent Federal Power Commission study of 168 offshore shut-in producible gas leases has conservatively estimated that these properties contain proved reserves of 4.7 billion mcf (thousand cubic feet) and an additional 3.3 billion mcf in probable reserves, a total two-and-one-half times actual offshore production in 1973. A significant portion of these gas reserves is in wells associated with producible quantities of oil. Over twothirds of these 168 shut-in leases are more than five years old. The FPC staff is attempting to determine why rational producers would develop these properties and then shut them in. See U.S. Federal Power Commission, Bureau of Natural Gas, Offshore Investigation: Producible Shut-in Leases (First Phase), January 1974 (March 1974), and Offshore Investigation: Producible Shut-in Leases As of January 1974 (Second Phase) (July 1974). 
for themselves. ${ }^{29}$ As long as the host nations competed with each other to grant concessions, however, they could receive the diminishing-returns rents at best. But once they organized a cartel, the market for OPEC properties became a type of bilateral monopoly situation, where the distribution of the total economic rents (of both sorts) is not determinate. Thus, as a number of experts have noted, the dispute between the operating companies and the African and Middle East governments "essentially, in economic terms, . . . is a question of the division of economic rent." 30

As landowners in the Middle East and Africa realized that large economic rents had escaped them because of their acceptance of the original concession contracts, they urged the formation of the OPEC cartel as a remedy. If, of course, the operating companies were passively to acquiesce in giving the landowners the economic rents that, under the initial contracts, had been their own, then, ceteris paribus, the actual degree of monopoly in the product market would remain unchanged and so would the price to consumers.

But suppose that host nations are now attempting to capture both diminishing-returns rents and the monopoly rents in the product market. As Chamberlin has demonstrated, competition for properties among producers makes landlords the ultimate recipient of all monopoly rents..$^{31}$ If the price elasticity of demand in the product market (that is, the degree of monopoly) was unchanged and if producers were already profit maximizing in the product markets, then consumer prices would not change. In this case again, the only effect of the OPEC cartel would be to redistribute the largesse of economic rents from the companies to the host nations. ${ }^{32}$

If, however, some unexploited monopoly power remains in the product market, the companies can attempt to recoup the higher payments to landowners from the ultimate consumers. Their success will depend on the

29. In a perfectly competitive property market, the present value of lease bonuses and future royalties would exactly equal the discounted values of these economic rents so that all diminishing-return rents would accrue to property owners. If producers had monopsonistic power either because of superior information or collusion on bids, they could keep some of these economic rents.

30. Michael V. Posner, Fuel Policy: A Study in Applied Economics (London: Macmillan, 1973), p. 52.

31. Edward H. Chamberlin, The Theory of Monopolistic Competition: A Re-orientation of the Theory of Value (7th ed., Harvard University Press, 1960), pp. 266-69.

32. This result still might cause balance-of-payments problems for the consuming nations, but as long as the OPEC nations are attempting merely to capture existing economic rents, their actions will not affect long-run marginal factor costs. 
price elasticity of demand of the consuming nations for OPEC oil. ${ }^{33}$ As long as either this demand is relatively inelastic, or additional monopoly power can be brought to bear, ${ }^{34}$ the operating companies will have a strong incentive to extract from consumers the net revenues lost in monopoly rents to the host governments. In fact, as the host nations have increased their receipts per barrel, the operating companies have raised product prices by an even greater absolute amount. For example, when the Persian Gulf nations raised their payments by the equivalent of 28 cents per barrel in February 1971, the matching price increase in Britain was 42 cents per barrel; ${ }^{35}$ thus the net revenues of the operating companies increased as they drew on previously unexploited monopoly power.

The incentive to form a coalition to limit supply and to convince the consuming nations that there is an energy crisis can be analyzed via the user cost inherent in all raw materials that involve these kinds of latent market power. If at or near current price levels the consumer has no good substitute from suppliers who have no economic interest in maintaining the potential monopoly rents for OPEC oil, and if governments of consuming nations leave the market unfettered, then the demand for OPEC oil will provide the possibility of additional exploitable monopoly rents. If OPEC oil suppliers-whether host nations or operating companies-believe that, by enforcing market sharing and production restrictions, a cartel can exploit additional market power by raising the prices to the consuming nations over time, then the marginal user cost is positive. Hence producers and landowners (who via royalties and taxes have a vested interest in higher prices) will pursue policies to restrict current production as long as incremental revenues are exceeded by incremental costs, including this

33. The elasticity of demand for OPEC oil will depend on the availability of substitutes provided by suppliers who have no interest in maintaining economic rents for OPEC oil. This point is developed below.

34. In a world of perfect certainty, profit-maximizing entrepreneurs would not leave monopoly power unexploited. In the real world, however, producers in the oil industry may be more interested in maintaining market shares than in maximizing profits. Producers may not always set profit-maximizing prices for fear of antitrust or other governmental action. In the absence of significant justifications for increases, prices may remain stable below profit-maximizing levels until they are released by severe market shocks, like the closing of the Suez Canal or the unified demands of OPEC. Then, in a world of uncertainty, where political crises can reduce the effectiveness of government responses to price increases producers may exploit latent monopoly power and also try to stimulate political and expectational conditions that create additional monopoly power.

35. The data on price increases are from the McGraw-Hill publication, Platt's Oilgram News Service, Vol. 49 (February 18, 1971), p. 2, and (February 23, 1971), p. 1-A. 
positive user cost, as they attempt to capture potential additional monopoly rents from consumers. The consumer must then either find a way to reduce the user costs to zero or else accept the higher price as tribute to the monopoly power of the suppliers.

\section{CONGLOMERATE ENERGY COMPANIES AND USER COSTS}

How has the growth of conglomerate energy companies affected the ability of the OPEC cartel to create positive user costs?

As has already been intimated, the existence of an exploitable monopoly position depends on the present and future price elasticity of demand in the relevant range. As far as the OPEC cartel is concerned, therefore, it depends in large measure on the current price in consuming countries and ultimately on the supply price at which alternative sources of energy will become significant substitutes for OPEC oil. Suppose, however, the supplier of a substitute energy source also has an economic interest in OPEC petroleum reserves, because it is a conglomerate energy company with an OPEC concession or other oil reserves. Then it will anticipate a positive user cost in providing the substitute if production of this substitute reduces potential profits from its oil reserves. This positive user cost will raise the supply price (above resource costs) of marketing the substitute.

In these circumstances this positive user cost of substitutes internalizes a cost that in a competitive economy would be external to an independent producer of a substitute energy source. Independent producers of domestic oil, shale, tar sands, coal, uranium, and so on, would not care if they inflicted capital losses on the value of foreign underground reserves of petroleum by providing a cheaper energy source. Most reasonable people would argue that society is the beneficiary of a decision to produce a less expensive substitute even though the oil producers and property owners would suffer a capital loss. The existence of rational, multisource, energyproducing conglomerates, however, constrains production of substitute fuels and reduces consumer welfare. The ability of conglomerates to maintain high prices for the substitutes tends to reinforce their monopoly power in marketing their OPEC oil.

If at the current price consumer demand for OPEC oil is therefore still in the exploitable range, a strong cartel of property owners can allow multinational energy conglomerates to continue to raise prices relative to real resource costs. The continuous revenue increases of host nations since 1970 seem to be attempts to search out the point at which demand for 
OPEC oil becomes so elastic that monopoly rents are fully exploited. (However, for any given demand situation with any degree of elasticity, higher prices require production restrictions, and hence at least tacit market-sharing arrangements to prevent one member of the cartel from increasing its gains at the expense of others.) Since the operating companies also have vested interests in the price of OPEC reserves as long as they retain any monopoly rents, they will be willing tools in maintaining an "orderly" production market.

If, however, the operating companies expected the host nation to nationalize the reservoirs soon without adequate compensation for their economic interests, the user costs of OPEC reserves would become negative to the producing firms, and they would try to increase the production flow even if that would drive down current prices to resource costs and destroy their market power. Thus, threats of nationalization without adequate compensation can only be detrimental to the interests of host nations, while favoring consuming nations.

\section{POLICY IMPLICATIONS OF USER COSTS}

In the light of recent experience, OPEC nations seem likely to pursue their attempts to capture more of the monopoly rents, and the companies their efforts to exercise all the available monopoly power in consumernation markets. Furthermore, even if no additional monopoly power remains to be exploited in the consuming nations but if the OPEC cartel is intact, monopoly rents will be redistributed from the operating companies (which are basically residents of the consuming nations) toward the OPEC nations, causing balance-of-payments problems and perhaps adverse changes in the terms of trade among the consuming nations. ${ }^{36}$ In such an ultimate situation, the operating companies would act as monopoly tax collectors for OPEC as all the monopoly rents are transferred to the host nations. $^{37}$

Since expectations of price-cost relations can, via the user cost inherent in all depletable resources, dictate the rate at which OPEC exploits its large

36. The loss in real income of the consuming nations resulting from this redistribution may take the form of high unemployment if the OPEC nations do not spend all of their claims on world income, and if the governments of the developed nations do not undertake compensating expansionary policies.

37. See Adelman, World Petroleum Market, p. 256. 
underground reserves in its search for maximum economic rents, user-cost expectations become crucial to the apparent worldwide energy crisis. The OPEC strategy on user costs depends on OPEC's view of the growth in demand of the consuming nations, and its estimates of the timetable and prices at which known and potential substitutes can be marketed.

User costs cut both ways-that is, expectations of higher prices tend to retard current exploitation of known OPEC reservoirs and exacerbate supply shortages, while expectations of lower prices will accelerate exploitation. In other words, if the OPEC countries expected the price of oil to decline over the next dozen years, they would want to augment the flow of oil now to take advantage of the higher prices available today and tomorrow. Hence the best interests of the consuming nations lie in policies that encourage the expectation of a decline in the price of OPEC crude by, say, 1980.

Accordingly, consuming nations should devise policies aimed at reducing the degree of monopoly in the energy-products market, or at least at containing it; and at breaking up the OPEC cartel to prevent redistribution of economic rents and the worsening of the terms of trade.

A policy for substitutes and curbing monopoly power. For consuming countries such as the United Kingdom, the United States, Western Europe, and Japan, the availability of substitutes rests on indigenous energy sources with low resource costs or importation of oil from low-cost, non-OPEC, regions.

Large additional reserves are unlikely to be available in the next decade from non-OPEC nations that are not themselves major consumers; and even if they were, such host nations would probably find their own selfinterest more compatible with joining OPEC than with attempting to lick it by underpricing its oil. Moreover, OPEC would probably see that its selfinterest was best served by accommodating these countries and sharing the fruits of the cartel with them. Hence the consuming nations are unlikely to find cheap substitutes for OPEC oil among other Third World countries.

Thus the major substitutes are oil and gas and other energy resources from properties within the boundaries of consuming nations or the adjacent continental shelf. Moreover, these substitutes should be developed by independent producers who have no vested interest in maintaining or improving the capitalized value of already proved oil reserves.

Accordingly, consumer nations such as the United States who happen to own most of the remaining unexplored potential fossil fuel-bearing 
properties within their national boundaries ${ }^{38}$ should adopt policies that accelerate leasing of offshore tracts and shale lands, and that promote development of the properties by independent producers and government energy corporations. ${ }^{39}$ Such policies would reduce the existing degree of monopoly in product markets and permit some intramarginal lands (which are being withheld by government edict) to be developed before forcing producers to move further out along the extensive margin. Further, requirements for rapid development and exploitation would diminish the ability of producers to maintain monopoly power in the product market by limiting production.

Increasing rates of exploitation of new reservoirs. If large new fields in consuming countries are currently coming on stream-for example, in the North Sea and Alaska - an announced policy of rapid exploitation, even at rates that exceed the maximum efficient rate of production (MER), ${ }^{40}$ will induce expectations of a decline in the price for OPEC oil. These expectations will be strengthened if an available substitute, such as shale or nuclear

38. The USGS estimates that the lower forty-eight states contain between 575 billion and 2.4 trillion barrels of oil reserves, while current proved reserves are only 37 billion barrels. See Sanford Rose, "Our Vast, Hidden Oil Resources," Fortune, Vol. 89 (April 1974), pp. 104-05. T. H. McColloh has reported that economically recoverable (at 197071 wellhead prices) oil reserves in the United States are from about three-and-one-half to ten times current proved reserves as reported by the industry. See United States Mineral Resources, USGS Professional Paper 20 (1973), pp. 491, 492. Since these two sets of estimates were made when wellhead prices were much lower, they significantly underestimate current economically recoverable reserves.

39. A change in the base contract from the constant-percentage royalty and frontloaded bonus should be undertaken to aid the smaller, independent, producers. For example, a bonus-variable royalty system under which the total bonus (plus accrued interest) would be paid on a schedule of annual payments out of sales receipts after the property is on stream would virtually eliminate the producers' flow-of-funds problem for financing property acquisitions. (If the property was abandoned before the total bonus bid was paid off, the producer would be liable for the remaining sum.)

40. MER is defined as the highest rate of production that can be sustained over a long period of time without reservoir damage or significant loss of ultimate oil and gas recovery. To the extent that there is a positive marginal user cost associated with any rate of flow that exceeds MER (see Davidson, "Public Policy Problems," pp. 91-94), a subsidy may have to be paid on oil produced in excess of MER in new fields that are under private corporate management. If the expected gain to the consuming nations in breaking the OPEC cartel and receiving their oil at a price closer to real resource costs exceeds this subsidy, such a policy would be desirable.

Some petroleum engineers claim that free (that is, not injected) gas saturation, which is created by fast production rates, actually enhances ultimate recovery from water-drive or water-flood mechanisms so that no case can be made for a loss of oil caused by production rates above MER. See Rose, “Our Vast, Hidden Oil Resources,” pp. 106, 182. 
power, is to be independently supplied in the foreseeable future. Once any OPEC member appreciates this eventuality, the cartel will begin to disintegrate and the increased production flow from indigenous fields competing with OPEC will tend to reduce monopoly power and increase supply.

\section{POLICY CONCLUSIONS}

In sum, the adoption by consuming nations of policies that promise to force down net demand prices for OPEC oil in the foreseeable future, but appear to permit host nations to capture some large monopoly rents currently, can have beneficial results for consuming nations. They will unleash economic forces that will encourage the break-up of the OPEC cartel, spur current production, and exert downward pressure on estimates of user cost. An essential condition for the success of this approach is the existence of an alternative energy source whose suppliers have no vested interest in maintaining the value of OPEC or other oil reserves. Thus, for example, if the development of the shale oil industry or the operation of the indigenous petroleum or coal industries in the United States is entrusted to conglomerate energy companies that have producing interests in OPEC or other oil reserves, the success of any attempt to provide a substitute, competitively priced, energy source will be seriously jeopardized. Accordingly, a vigorous domestic antitrust policy to dissolve conglomerate "energy companies" into independent domestic and foreign companies dealing with only one energy resource is an essential element in a national energy policy.

Any policy that is expected to reduce monopoly power in the product market over time will create negative user costs and accelerate current production and hence ease the energy crisis. Thus vigorous antitrust policies and consuming-government regulation of, or participation in, the operations of producing companies can, alone or in combination, force the producers to accept a more competitive return on their investment, and thereby eliminate monopoly rents and provide consumers with fuels at lower prices.

\section{Market Price for Self-Sufficiency in Oil in $\mathbf{1 9 8 0}$}

This section presents estimates of the long-run market-clearing prices for oil that would be consistent with U.S. self-sufficiency in 1980 . 


\section{Figure 1. U.S. Supply and Demand for Crude Oil, 1971 and 1980a}

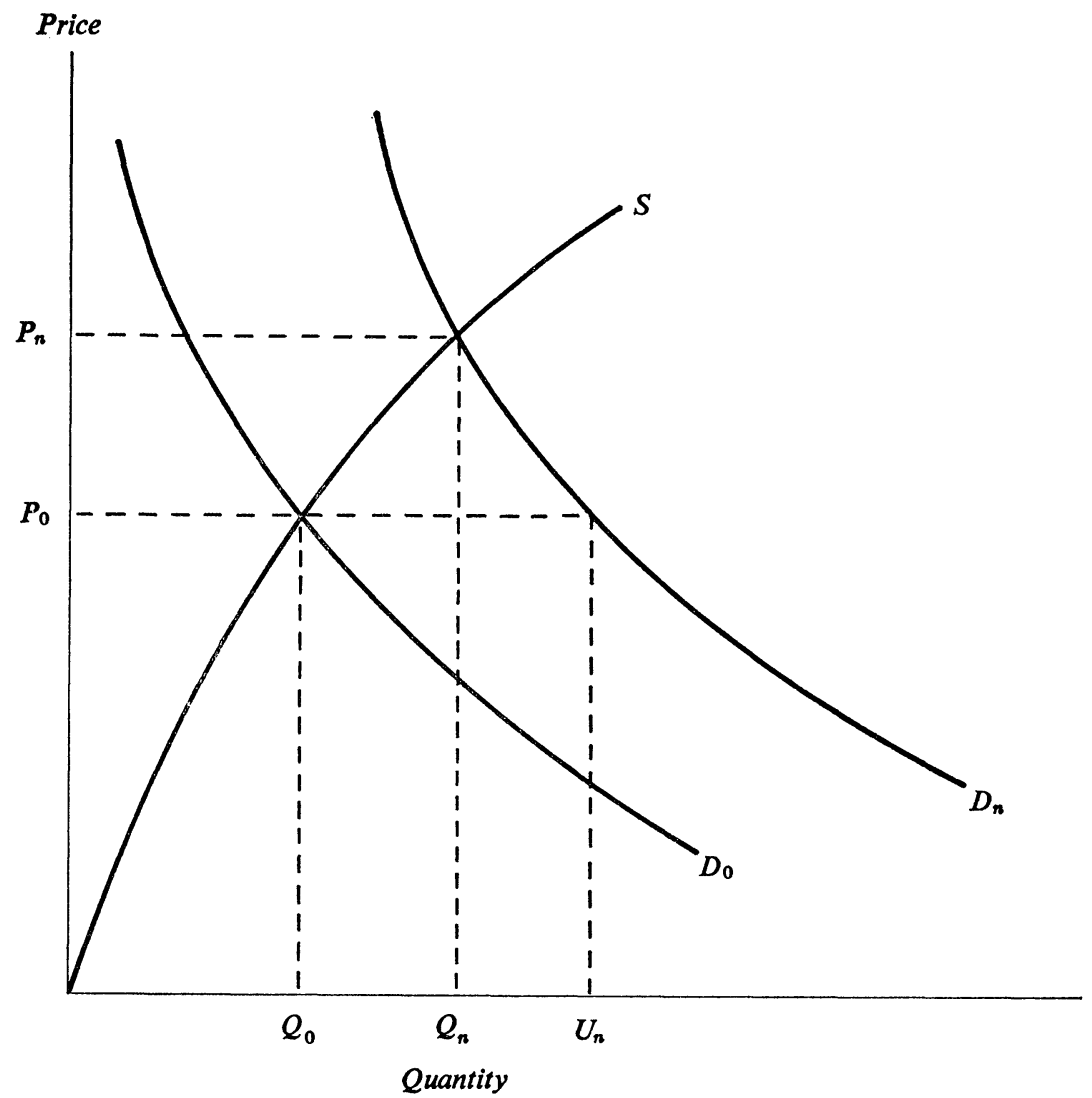

Source: See text for detailed explanation.

a. $D, P, Q=$ demand, price, and U.S. production, respectively

$0, n=$ subscripts indicating 1971 and 1980 , respectively

$U_{n}=$ U.S. demand in 1980 at 1971 price

$S=$ long-run supply.

Figure 1 represents the basic model. Given the degree of monopoly in the petroleum industry, the curve $S$ represents the supply path for crude oil for the United States in the long run (where user costs are zero); ${ }^{41} D_{0}$ is the U.S. demand curve for oil net of imports in the base period, 1971.

41. In what follows we use the phrase "long-run supply path" merely to denote a supply curve in which user costs are zero and the only components of the flow-supply price are Keynes' prime and supplementary factor costs including any historical monopoly rents. (See Keynes, General Theory, pp. 23-24, 67-68.) Our long-run supply price associated with production flows includes all factor payments to labor and capital 
Accordingly, $Q_{0}$ is U.S. production in the base period, $P_{0}$ is the domestic crude price in the base period, U.S. consumption would be $Q_{0}$ plus imports $\left(M_{0}\right)$ in the base period, and $U_{n}$ represents the estimated total quantity of crude oil that would be demanded in the United States in 1980, at the base period price. This quantity lies on the 1980 total U.S. demand curve, $D_{n}$, which is assumed to have the same (constant) price elasticity as the baseperiod demand curve, $D_{0}$. Hence, in Figure $1, P_{n}$ represents the 1980 market-clearing price for full self-sufficiency-that is, meeting all U.S. demand for crude oil from U.S. production, $Q_{n}$.

We have explored three variations on this basic model. They assume (1) that some given quantity of imports from what we term "friendly" oilproducing nations, such as Canada and Venezuela, will be available to meet some part of U.S. demand in 1980; (2) that other energy sources will become more important relative to oil in supplying U.S. needs in 1980; and (3) that the degree of monopoly in the crude oil-producing industry will be zero-that is, market price will just equal long-run marginal factor costs. In applying the basic long-run supply model, we assume that the time between now and 1980 is sufficient to obtain the increased production associated with $Q_{n}$ on our long-run supply path. In the final section below, we suggest why we think that, given proper governmental actions, there is no technical constraint on achieving the necessary adjustment in production by 1980 .

The following sections present the formal analysis of the calculations made and the data base used for the empirical estimates of prices and production quantities underlying self-sufficiency in 1980. Included is an analysis of the sensitivity of our 1980 price estimates to reasonable variations in the elasticities of supply and demand to price.

\section{THE ANALYTICAL MODELS}

Full self-sufficiency. Assuming constant price elasticities for both supply and demand, the supply equation is specified as $Q=a P^{b}$, where $b$ is the

(including finding and development costs). Consequently, at any point of time the supply prices of remaining reserves exceed zero only to the extent that they embody capitalized past finding and developing costs that have not yet been paid for out of sales revenues. In adopting this view we are emphasizing the important economic difference between finding what exists and creating something new. Nature, not man, produced mineral deposits and Nature's long-run supply price is zero. In the long run only finding, developing, and producing costs must be paid for. 
long-run supply price elasticity and $a$ is an arbitrary constant; and the demand equation is $Q=\alpha P^{-\beta}$, where $\beta$ is the constant price elasticity of demand and $\alpha$ is an arbitrary constant. ${ }^{42}$ Then the equilibrium price is the one that satisfies the condition $a P^{b}=\alpha P^{-\beta}$. The 1980 market-clearing price, $P_{n}$, as shown in Figure 1, is computed as ${ }^{43}$

$$
P_{n}=e^{\lambda} \text {, }
$$

where

$$
\lambda=\frac{\ln U_{n}-\ln Q_{0}+(b+\beta) \ln P_{0}}{b+\beta} .
$$

The quantity produced in 1980, $Q_{n}$ in Figure 1 , is obtained by substituting equation (1) into the supply equation to yield

$$
Q_{n}=e^{\phi} \text {, }
$$

where

$$
\phi=\ln Q_{0}-b \ln P_{0}+b \ln P_{n} .
$$

Allowing for some imports or substitution. If imports form part of the supply in 1980, the market price will be lower than that computed under the assumption of full self-sufficiency. We have analyzed the simplest case by assuming that the ratio of imports to domestically produced crude oil will remain unchanged from the base period, so that the market-clearing price is adjusted downward by replacing $Q_{0}$ in equation (1a) with $\left(Q_{0}+M_{0}\right)$, where $M_{0}$ is the quantity of crude oil imported from specific friendly countries during the base period:

$$
P_{n}=e^{\theta},
$$

where

$$
\theta=\frac{\ln U_{n}-\ln \left(Q_{0}+M_{0}\right)+(b+\beta) \ln P_{0}}{b+\beta} .
$$

Similarly, if, say, indigenous coal becomes an important substitute for crude oil, then in equations (1a) and (2a), $U_{n}$ is reduced by the amount of additional coal used in the $n$th year, and the system is then solved as in the basic case.

42. The supply equation is obtained by solving the differential equation

$$
b=(d Q / d P)(P / Q),
$$

where $b$ is the constant price elasticity. A similar procedure yields the demand equation.

43. Derivation available from the authors upon request. 
Zero degree of monopoly. The degree of monopoly power, $m$, exercised by producers in any market can be measured by $m=(P-M C) / P$, where $P$ is product price and $M C$ is marginal resource costs. Such a measure implies a markup over marginal costs of

$$
\frac{1}{1-m}-1
$$

This markup is compatible with either profit maximization (in which case $m$ is equal to the reciprocal of the price elasticity of demand at the point where price and output maximize profit) or with a conventional markup over marginal resource costs in a world of uncertainty where profit maximization may be elusive.

As long as the degree of monopoly is the same at each level of production, it can be shown that the elasticity of a supply function under an unchanging degree of monopoly ${ }^{44}$ is equal to the elasticity of the comparable competitive supply function, $M C{ }^{45}$ With $S\left(m_{x}\right)$ representing supply under a given degree of monopoly, Figure 2 depicts a family of long-run supply paths, exemplified by $S\left(m_{0}\right), S\left(m_{1}\right)$, and $S\left(m_{2}\right)$, where $S\left(m_{0}\right)$ represents the supply curve when the degree of monopoly is zero, and the others represent longrun supply paths associated with different degrees of monopoly. If in the base period the degree of monopoly was $m_{2}$, then in Figure 2 (as in Figure 1) $P_{0}$ and $Q_{0}$ represent the base price and quantity, respectively, while $P_{0}\left(m_{0}\right)$ represents the base-period price for that level of output in the total absence of monopoly. Thus, if the degree of monopoly in 1980 remains $m_{2}$, the 1980 self-sufficiency price and quantity are $P_{n}$ and $Q_{n}$ in Figure 2 (the same solution as in Figure 1). If, however, the degree of monopoly is reduced to zero in 1980, then by definition the 1980 self-sufficiency price would be less than $P_{n}$. In fact, under these assumptions, solution of equations (1a) and (2a) of the basic model gives 1980 prices, $P_{n}\left(m_{0}\right)$, below $P_{n}$, the 1980 self-sufficiency price of our basic model. That result provides good reason for (1) vigorous antitrust action, or (2) some form of government

44. Economic textbooks often claim that there is no supply function with monopoly in the product market; for example, see George J. Stigler, The Theory of Price (3rd ed., Macmillan, 1966), pp. 212-13. In fact, a supply function can be specified only when the degree of monopoly is determined-that is, the supply curve is always derived for alternative expected demand curves. It is only the assumption of a zero degree of monopoly that permits the textbooks to derive the marginal cost curve as the supply function in the purely competitive case. Given the cost function, the degree of monopoly, and entrepreneurial behavior, a supply path can always be derived.

45. A proof is available upon request from the authors. 
Figure 2. U.S. Supply and Demand for Crude Oil, with Different Degrees of Monopoly, 1971 and $1980^{a}$

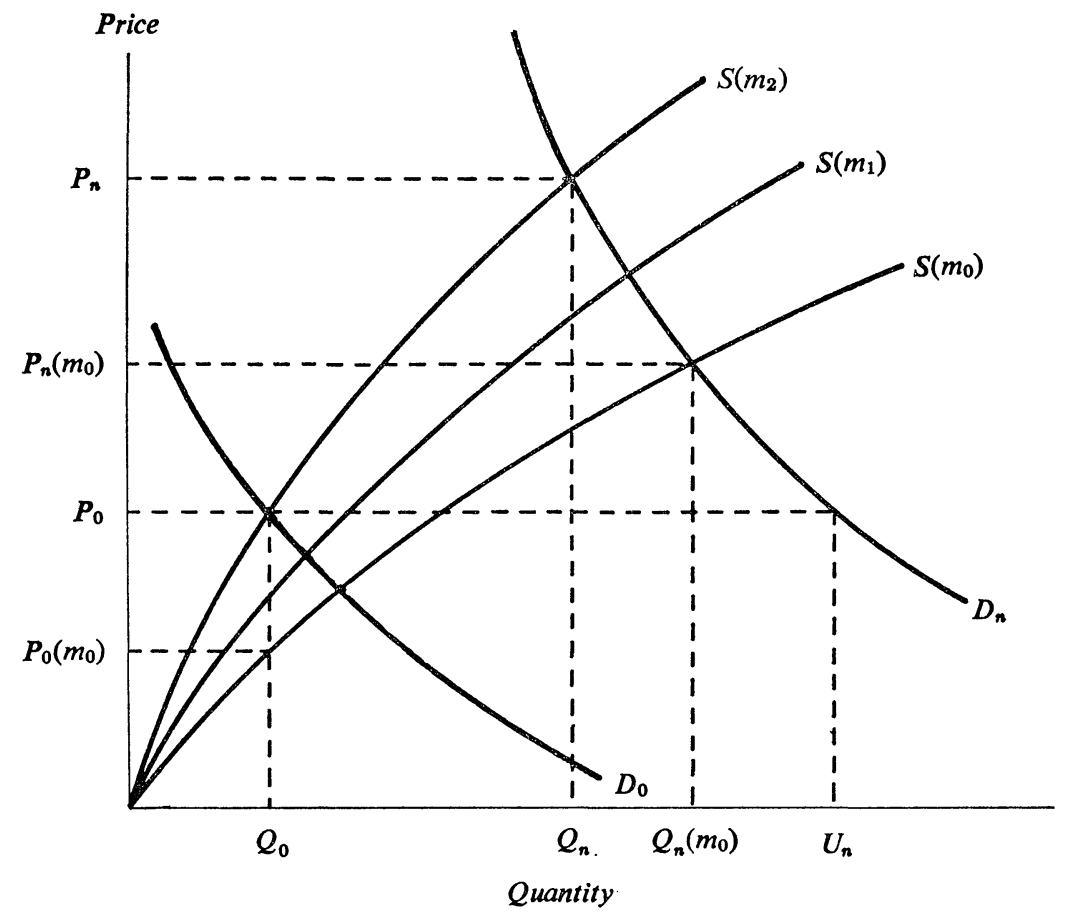

Source: See text for detailed explanation.

a. $m_{x}=$ degree of monopoly (for example, $m 0$ represents a zero degree).

Other symbols are as defined for Figure 1.

regulation, or (3) a government corporation-or some combination of the three-to foster a reduction in the degree of monopoly in the industry. ${ }^{46}$ We discuss these alternatives below.

\section{Estimates of Prices, Quantities, and Elasticities for the Model}

Estimation of 1980 prices and production under self-sufficiency requires data on, first, the wellhead price and U.S. production in the base period

46. Senator Adlai E. Stevenson III has suggested that a Federal Oil and Gas Corporation (FOGCO) be created to explore for, develop, and produce oil and gas on lands owned by the federal government. 
$\left(P_{0}\right.$ and $\left.Q_{0}\right)$; second, the 1980 quantity of crude oil that would be demanded at the base-year price, $U_{n}$; and third, the price elasticities of demand and supply.

\section{BASE-PERIOD PRICE AND QUANTITY}

In 1971 domestic crude oil production was near "capacity" as marketdemand prorationing restrictions became less constraining. Since the end of 1971 domestic crude-oil prices have been under government controls. We have, therefore, taken the average 1971 wellhead price of $\$ 3.35$ per barrel and 1971 domestic production of 9.5 million barrels per day as base-period magnitudes lying on the long-run supply path, $S$, in Figure $1 .^{47}$ In essence we are assuming (1) that statistics for the years prior to 1971 may not lie on the long-run supply path because of prorationing production restrictions; and (2) that prices and production statistics since 1971 are likely to reflect temporary government controls and positive user costs generated by the increasing strength of the OPEC cartel and the disruption of the Middle East War, so that data since 1971 are likely to lie above the long-run supply curve.

\section{QUANTITY DEMANDED IN 1980}

For the quantity of crude oil that would be demanded in 1980 at the base-period price, we have taken the projection of the National Petroleum Council. NPC estimates an increase in total domestic oil demand from 14.7 million barrels per day in 1970 (including all imports of crude and refined products) to 22.3 million barrels per day in 1980 , or 4.25 percent per year. ${ }^{48}$ To obtain net demand for crude oil from the NPC statistics, we subtracted the production of natural-gas liquids of 1.7 million barrels per day

47. Price statistics from World Oil, Vol. 174 (February 15, 1972), p. 21 ; quantity statistics from Oil and Gas Journal, Vol. 70 (January 31, 1972), p. 87. The latter source (p. 93) was also used for base-period import statistics from Canada and Venezuela in our model assuming imports from friendly nations.

48. National Petroleum Council, U.S. Energy Outlook: An Initial Appraisal, 19711985 (1971), Vol. 2, p. 15. The projection assumed that the economic environment would remain unchanged throughout the period 1971-85. Hence it appears to be equivalent to our $U_{n}$ concept. 
$(\mathrm{MMB} / \mathrm{d})$ in 1970 . We estimated that production of natural-gas liquids will increase by 2.2 percent a year over the decade and therefore subtracted 2.1 MMB/d from the NPC projection of total demand to obtain 20.2 $\mathrm{MMB} / \mathrm{d}$ in 1980 as our estimate of $U_{n}$.

\section{ELASTICITY ESTIMATES}

Supply elasticity. Despite the intensive study of the petroleum industry by economists over the years, there is a paucity of estimates of supply elasticities for crude oil. Since this is a vertically integrated industry, reliable data on the response, at the wellhead, of supply to the market price is extremely difficult to obtain. Moreover, the technology of oil production, which involves a long gestation period between well drilling and production flows, makes it extremely difficult empirically to relate changes in market prices at given points in time with the flow-supply responses over time. Because we believe these formidable problems make direct estimate of supply elasticities of crude oil difficult, if not impossible, we attempted in an earlier paper to estimate the supply elasticity indirectly, using the theory of economic rents. ${ }^{49}$

49. Paul Davidson, Laurence Falk, and Hoesung Lee, "The Relations of Economic Rents and Price Incentives to Oil and Gas Supplies," in G. Brannon (ed.), Studies in Energy Tax Policy (Ballinger, 1974), pp. 115-55.

Some may believe that a stock-supply elasticity of additions to reserves rather than a flow-supply elasticity of oil production is relevant. We disagree for a number of reasons.

Since proved reserves are merely "shelf inventory" for oil producers, the reserve elasticity would be a good proxy for the relevant Marshallian production-flow elasticity if it is assumed that shelf inventory is continuously maintained as a constant proportion to sales. But Project Independence is a production-flow goal and not a shelf-inventory goal, and a constant reserves-production ratio in oil is no more necessary than is an unchanging inventory-sales ratio in other economic activities; therefore, a reserve elasticity estimate is not the most relevant concept. Certainly no particular level of reserves is necessary for 1980 .

Moreover, actual changes in the ratio of reserves to production flows will reflect (1) changes in the interest rate; (2) changes in user cost ; (3) the technological fact that additions to reserves are lumpy; and (4) changes in wellhead prices and costs. Therefore, an empirical reserve elasticity based on past data is unlikely to reflect accurately the production-flow elasticity. Finally, statistics on proved reserves as reported by the industry are more likely to be biased and unreliable than production statistics, and hence any empirical estimates of reserve elasticity are less reliable than a production-flow elasticity. 
Using the "as if" methodology of positive economics, ${ }^{50}$ then, for any given degree of monopoly, we can estimate the supply elasticity in terms of payments to landowners (economic rents) as

$$
E_{s}=\frac{1-\alpha}{\alpha},
$$

where $E_{s}$ is the long-run elasticity of supply and $\alpha$ is the proportion of the value of shipments that is paid to property owners. ${ }^{51}$ Thus, the greater is $\alpha$, the less elastic is the supply of petroleum. ${ }^{52}$ If, for example, supply were almost perfectly elastic, payments to landowners would be insignificant, $\alpha$ would be negligible, and $E_{s}$ would approach infinity. If, on the other hand, supply were very inelastic, payments to landowners would envelop most of the value of shipments, $\alpha$ would be very large, and $E_{s}$ would approach zero.

Using data from the U.S. Department of the Interior on payments to property owners and the value of shipments for petroleum properties on the U.S. continental shelf, we estimated that $E_{s}$ was approximately 1.4 for the years $1953-71$ and 1.6 for 1971, and projected it at approximately 1.8 by 1980. Since we believe that most additional U.S. production will come from olfshore properties, we prefer the 1971 base-year $E_{s}$ of 1.6. In Tables 1-4, however, we also show the differences involved in using plausible estimates on either side of 1.6.

Demand elasticity. Both the income and price elasticities of demand are relevant to our 1980 estimates of demand. The NPC projection involved a 4.25 percent annual growth in demand (at the base-period price) in conjunction with a 3.9 percent annual growth in GNP. Thus the NPC forecast, which we used, implicitly assumed an income elasticity of 1.1 .

50. For a discussion of this approach see Milton Friedman, Essays in Positive Economics (University of Chicago Press, 1953; fifth impression, 1966), Pt. 1.

51 . For any given property at any given time the marginal cost schedule of annual production flows might be expected to shift upward over time (unless offset by productivity gains). Since each producer considers these expectations of changing costs and productivity gains over the life of the property when he enters into a lease contract, $\alpha$ will reflect them. Hence our supply elasticity reflects the expected "average" elasticity of the marginal costs of production flows over the life of each property. While the "average" elasticity in the aggregate can change over time, it is not likely to change drastically over a decade, since it is tied to the average life of properties, which normally exceeds two decades.

52. In "Relations of Economic Rents," we discuss at length some of the limitations of this measure. Nevertheless, we believe that this approach does provide a "ballpark" supply estimate for others to discuss or even shoot at. 
Studies of the price elasticity of demand $\left(E_{d}\right)$ have usually suggested a value in the inelastic range. The Cabinet Task Force used an estimate of 0.1, which Standard Oil Company (N.J.) provided, but its report gave no documentary support for this elasticity. ${ }^{53} \mathrm{~A}$ study by Burrows and Domencich reported a higher, but still inelastic, price elasticity of $0.5 .^{54}$ In most of the following discussion of our estimates of the price and production outcomes in 1980, we use $E_{s}=1.6$ and $E_{d}=0.5$ as, in our view, the most reasonable values.

\section{Empirical Results}

The results of our analysis are summarized in Tables 1 through 4. All prices in the tables are expressed in terms of 1974 dollars: hence, the wellhead price in the 1971 base period in 1974 dollars is \$3.74-compared with the actual 1971 price of $\$ 3.35 .^{55}$ All quantities are reported in millions of barrels per day.

Table 1 summarizes the market-clearing prices and quantities for full self-sufficiency in 1980 - that is, no reliance on imports-at various elasticities. Taking 1.6 and 0.5 as the most reasonable elasticities for supply and demand, respectively, the market-clearing price would be $\$ 5.36$ (in 1974 dollars) and the quantity supplied would be $16.9 \mathrm{MMB} / \mathrm{d}$. If $E_{s}$ was as low as 1.4 and $E_{d}$ was as low as 0.1 , the price at full self-sufficiency, given the degree of monopoly, might be as high as $\$ 6.19$ per barrel, while 19.2 MMB/d would be produced. Table 1 also presents price and production estimates for other elasticities. ${ }^{56}$

53. Cabinet Task Force on Oil Import Control, The Oil Import Question, A Report on the Relationship of Oil Imports to the National Security (U.S. Government Printing Office, 1970), p. 226.

54. See James C. Burrows and Thomas A. Domencich, An Analysis of the United States Oil Import Quota (Heath-Lexington, 1970), pp. 106, 119-29. The negative signs of $E_{d}$ are omitted throughout.

55. The price adjustment is made by first removing the fuel-price component from the GNP implicit price deflator for both periods, and then extrapolating the 1971 wellhead price to 1974 dollars, in proportion to the change in corrected GNP deflators between the two periods.

56. Spann and his associates have estimated a supply elasticity of 0.9 , which is reflected in the first row of the table. Since their model utilizes a Cobb-Douglas function with production as the dependent variable, it can be shown that their supply-elasticity formula is comparable to ours. According to note 17 of their paper (p. 1320), the sum of 
Table 1. Estimates of Market Price and Quantity for Full U.S. Self-Sufficiency in Oil in 1980, by Selected Elasticities

Prices in 1974 dollars; quantities in millions of barrels per day

\begin{tabular}{|c|c|c|c|c|c|c|c|c|}
\hline \multirow{3}{*}{$\begin{array}{l}\text { Elasticity } \\
\text { of supply }\end{array}$} & \multicolumn{8}{|c|}{ Elasticity of demand } \\
\hline & \multicolumn{2}{|c|}{0.08} & \multicolumn{2}{|c|}{0.1} & \multicolumn{2}{|c|}{$0.5^{\mathrm{s}}$} & \multicolumn{2}{|r|}{1.0} \\
\hline & Price & Quantity & Price & Quantity & Price & Quantity & Price & Quantity \\
\hline 0.9 & 8.08 & 19.0 & 7.96 & 18.7 & 6.42 & 15.4 & 5.57 & 13.6 \\
\hline 1.4 & 6.23 & 19.4 & 6.19 & 19.2 & 5.57 & 16.6 & 5.13 & 14.8 \\
\hline $1.6^{\mathrm{a}}$ & 5.87 & 19.5 & 5.84 & 19.3 & 5.36 & 16.9 & 5.00 & 15.1 \\
\hline 1.8 & 5.59 & 19.6 & 5.57 & 19.4 & 5.20 & 17.1 & 4.90 & 15.4 \\
\hline 2.0 & 5.38 & 19.6 & 5.36 & 19.5 & 5.06 & 17.4 & 4.81 & 15.7 \\
\hline
\end{tabular}

Sources: Authors' model discussed in the text, where the sources of the basic data are also given. a. Authors' preferred estimate.

Figure 3 can be used to interpret the results in Table 1. The $S$ curve is the long-run supply path; $D_{0}, D_{c}$, and $D_{n}$ are the demand curves in the 1971 base period, the current period, and 1980 , respectively; $P_{0}$ is the 1971 price of $\$ 3.74 ; Q_{0}$ is the 1971 production of $9.5 \mathrm{MMB} / \mathrm{d}$; and $U_{n}$ is the demand projection for 1980 of $20.2 \mathrm{MMB} / \mathrm{d}$. The current (January 1974) wellhead price, $P_{c}$, is $\$ 6.63$ and the (almost) vertical $S_{c}$ line represents the current short-run supply curve, with $Q_{c}$ being 1974 U.S. production of $9.2 \mathrm{MMB} / \mathrm{d}$. (The fact that $Q_{c}$ is less than $Q_{0}$ is compatible with short-run positive user costs in the current period.)

Using $E_{s}=1.6$ and $E_{d}=0.5$, the 1980 market-clearing price is given by the intersection of the $S$ and $D_{n}$ curves as $P_{n}$ (\$5.36), while 1980 production is $Q_{n}(16.9 \mathrm{MMB} / \mathrm{d})$.

After we had completed our calculations, a study group at MIT published an estimate for the market price for self-sufficiency in $1980 .{ }^{57}$ Using a mixture of econometric and judgmental models (including the NPC forecasts), they concluded that "the price of energy would be from $\$ 10.00$ to $\$ 12.00$ per barrel if supplies were limited to those within the United

their $\alpha+\beta$ equals one minus the rent share, and hence their supply-elasticity formula, which is $(\alpha+\beta) /(1-\alpha-\beta)$, is identical with our equation (4). See Robert M. Spann, Edward W. Erickson, and Stephen W. Millsaps, "Percentage Depletion and the Price and Output of Domestic Crude Oil," in General Tax Reform, Panel Discussion before the House Committee on Ways and Means, 93 Cong. 1 sess. (1973), Pt. 9, pp. 1318-20.

57. The Policy Study Group of the M.I.T. Energy Laboratory, "Energy Self-Sufficiency: An Economic Evaluation,” Technology Review, Vol. 76 (May 1974), pp. 23-58. 
Figure 3. U.S. Supply and Demand for Crude Oil, Model Results, 1971, 1974, and $1980^{\mathrm{a}}$

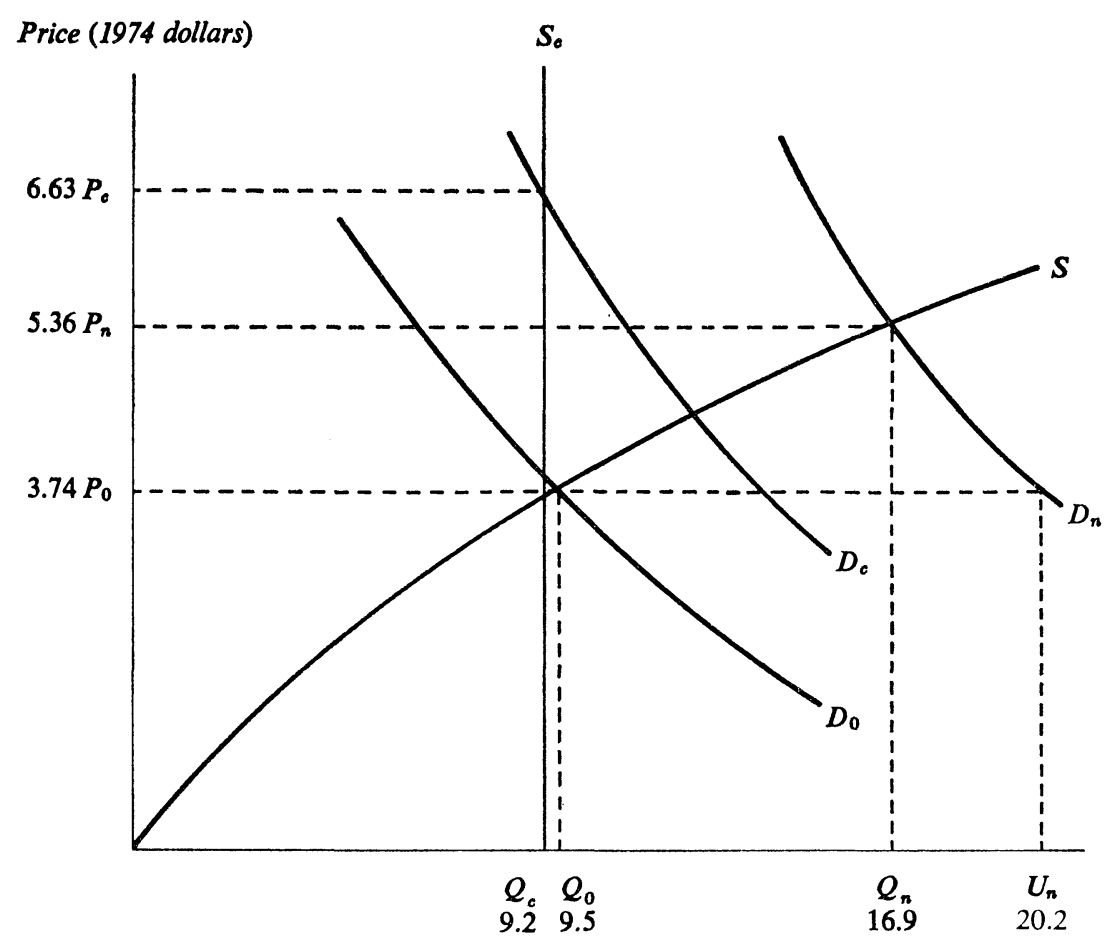

Quantity (millions of barrels per day)

Source: Interpreted from Table 1. See text for detailed explanation.

a. $c=$ subscript indicating 1974 current period. Other symbols are as defined for Figure 1.

States." 58 The MIT study differs from ours in that the authors attempted merely to find the price at which total demand and total supply for all fossil fuels and nuclear sources combined were in balance in 1980, whereas we have calculated the price for balancing demand and supply for oil separately. Nevertheless, the MIT results on price appear to be much higher than ours. If the two studies are compared on a common base (such as our simple model of Figure 1), the difference is readily explained.

The MIT group used the Erickson-Spann estimate of supply elasticity of 0.9 and the Hudson-Jorgenson estimate of demand elasticity of 0.15 as a

58. Ibid., p. 28. 
basis for the $\$ 10.00$ to $\$ 12.00$ estimate of $P_{n}$ (in Figure 1). Plugging these elasticity estimates into our model and solving for $P_{0}$-the long-run supply price in 1971 that would be consistent with this range for the self-sufficiency price in 1980-we estimate that the MIT group is implicitly assuming a 1971 price of between $\$ 5.10$ and $\$ 6.30$ (in 1974 dollars). We think this range for implicit base-period prices is much too high, and we suspect that the MIT group either let the short-run 1973 price of $\$ 5.49$ (which was dominated by user cost) color their views or assumed that speculative withholdings will continue to be profitable in 1980 because of the lack of appropriate government policy. ${ }^{59}$ Table 1 indicates that if $\$ 3.74$ is a more appropriate estimate of the long-run supply price in the base period, the MIT elasticities suggest a price of under $\$ 8.00$ for self-sufficiency in 1980 .

The effect on market price and quantity of allowing for imports of crude oil from Canada and Venezuela (in the same proportion to total U.S. production as in the base period) is shown in Table 2. Given our preferred elasticities, the 1980 price would be $\$ 5.11$ per barrel. If supply elasticity were as low as 1.4 and demand elasticity as low as 0.1 , the projected price would rise to $\$ 5.79$ per barrel. A comparison of Tables 1 and 2 suggests that the importation of Canadian and Venezuelan oil is likely to reduce the market-clearing price by approximately 4.7 percent and domestic production by approximately 7.7 percent. Thus, it appears that imports from friendly foreign sources are not likely to lower the price of "Project Independence" dramatically.

Table 3 displays estimates of the market price for self-sufficiency if no monopoly at all existed in the oil industry-in other words, if price were just equal to long-run marginal resource cost. To estimate the zeromonopoly price in the base period, we took Nordhaus' estimate of "the competitive supply price for domestic petroleum" 60 of $\$ 2.33$ in 1970, and

59. Another possibility is that the MIT group implicitly assumed that long-run real marginal factor costs for any given production flow will increase over time from 36 to 68 percent more than producers' historical expectations of cost changes as reflected in $\alpha$. (This possibility was implied in some comments by Charles L. Shultze, in which he argued that increasing marginal cost over time is a special characteristic of depletable natural resources. Although this may be a characteristic for any given property at any point of time, as note 51 indicates, we do not believe it is a necessary characteristic of the aggregate of producing properties considered over time.) The 1973 price of $\$ 5.49$ is the midyear weighted average of prices for "new" and "old" crude oil, calculated from World Oil, Vol. 178 (February 15, 1974), p. 73.

60. Nordhaus, "Allocation of Energy Resources," p. 557. Nordhaus notes that this price is the "long-run competitive supply price." 
Table 2. Estimates of Market Price and Quantity of Crude Oil for the United States in 1980, Allowing for Imports from Canada and Venezuela, by Selected Elasticities

Prices in 1974 dollars; quantities in millions of barrels per day

\begin{tabular}{|c|c|c|c|c|c|c|c|c|}
\hline \multirow{3}{*}{$\begin{array}{l}\text { Elasticity } \\
\text { of supply }\end{array}$} & \multicolumn{8}{|c|}{ Elasticity of demand } \\
\hline & \multicolumn{2}{|c|}{0.08} & \multicolumn{2}{|r|}{0.1} & \multicolumn{2}{|c|}{$0.5^{\mathrm{a}}$} & \multicolumn{2}{|c|}{1.0} \\
\hline & Price & Quantity & Price & Quantity & Price & Quantity & Price & Quantity \\
\hline 0.9 & 7.30 & 17.3 & 7.20 & 17.1 & 5.97 & 14.5 & 5.28 & 13.0 \\
\hline 1.4 & 5.83 & 17.6 & 5.79 & 17.5 & 5.28 & 15.4 & 4.92 & 13.9 \\
\hline $1.6^{\mathrm{a}}$ & 5.53 & 17.7 & 5.50 & 17.6 & 5.11 & 15.6 & 4.82 & 14.2 \\
\hline 1.8 & 5.30 & 17.8 & 5.28 & 17.7 & 4.98 & 15.9 & 4.73 & 14.5 \\
\hline 2.0 & 5.13 & 17.8 & 5.11 & 17.7 & 4.86 & 16.0 & 4.66 & 14.7 \\
\hline
\end{tabular}

Sources: Same as Table 1.

a. Authors' preferred estimate.

Table 3. Estimates of Market Price and Quantity of Crude Oil for U.S. Full Self-Sufficiency in 1980, Assuming Perfect Competition, by Selected Elasticities

Prices in 1974 dollars; quantities in millions of barrels per day

\begin{tabular}{|c|c|c|c|c|c|c|c|c|}
\hline \multirow{3}{*}{$\begin{array}{l}\text { Elasticity } \\
\text { of supply }\end{array}$} & \multicolumn{8}{|c|}{ Elasticity of demand } \\
\hline & \multicolumn{2}{|c|}{0.08} & \multicolumn{2}{|c|}{0.1} & \multicolumn{2}{|c|}{$0.5^{\mathrm{a}}$} & \multicolumn{2}{|c|}{1.0} \\
\hline & Price & Quantity & Price & Quantity & Price & Quantity & Price & Quantity \\
\hline 0.9 & 5.87 & 19.5 & 5.82 & 19.3 & 5.13 & 17.3 & 4.72 & 16.0 \\
\hline 1.4 & 4.48 & 19.9 & 4.47 & 19.8 & 4.31 & 18.8 & 4.18 & 18.1 \\
\hline $1.6^{\mathrm{a}}$ & 4.21 & 20.0 & 4.21 & 20.0 & 4.11 & 19.3 & 4.04 & 18.7 \\
\hline 1.8 & 4.01 & 20.1 & 4.00 & 20.1 & 3.96 & 19.7 & 3.92 & 19.3 \\
\hline 2.0 & 3.85 & 20.2 & 3.85 & 20.1 & 3.83 & 20.0 & 3.82 & 19.8 \\
\hline
\end{tabular}

Sources: Same as Table 1.

a. Authors' preferred estimate.

converted it first into our zero-monopoly, 1971 base-period price by increasing it in proportion to the actual change in wellhead prices between the two years, and then into 1974 dollars by the procedure used to construct the base price underlying Table 1 .

The estimated zero-monopoly price for full self-sufficiency in 1980 is $\$ 4.11$ (assuming $E_{s}=1.6$ and $E_{d}=0.5$ ), only 9.9 percent higher than the 1971 base-period monopoly price and dramatically lower than current 
Table 4. Estimates of Market Price and Quantity of Crude Oil for Full U.S. Self-Sufficiency in 1980, Assuming Increased Substitution of Coal for Oil

Prices in 1974 dollars; quantities in millions of barrels per day

\begin{tabular}{|c|c|c|c|c|c|c|c|c|}
\hline \multirow{3}{*}{$\begin{array}{l}\text { Elasticity } \\
\text { of supply }\end{array}$} & \multicolumn{8}{|c|}{ Elasticity of demand } \\
\hline & \multicolumn{2}{|c|}{0.08} & \multicolumn{2}{|c|}{0.1} & \multicolumn{2}{|c|}{$0.5^{\mathrm{a}}$} & \multicolumn{2}{|c|}{1.0} \\
\hline & Price & Quantity & Price & Quantity & Price & Quantity & Price & Quantity \\
\hline 0.9 & 6.13 & 14.8 & 6.07 & 14.7 & 5.29 & 13.0 & 4.83 & 11.9 \\
\hline 1.4 & 5.19 & 15.0 & 5.17 & 14.9 & 4.83 & 13.6 & 4.58 & 12.6 \\
\hline $1.6^{\mathrm{a}}$ & 4.99 & 15.1 & 4.97 & 15.0 & 4.71 & 13.7 & 4.51 & 12.8 \\
\hline 1.8 & 4.84 & 15.1 & 4.83 & 15.0 & 4.62 & 13.9 & 4.45 & 13.0 \\
\hline 2.0 & 4.72 & 15.1 & 4.71 & 15.1 & 4.54 & 14.0 & 4.40 & 13.1 \\
\hline
\end{tabular}

Sources: Same as Table 1.

a. Authors' preferred estimate.

prices. Hence, if antitrust or other governmental policies markedly reduced the degree of monopoly in the domestic crude-oil industry, self-sufficiency in 1980 would be achievable and compatible with lower costs than consumers are currently paying. In other words, even in the absence of cheaper Middle Eastern oil, the age of cheap energy for U.S. consumers need not be over. ${ }^{61}$

Table 4 estimates the effects of increased substitution of coal for crude oil on the 1980 full self-sufficiency price. Using the U.S. government's assumption $^{62}$ that coal production (in terms of millions of barrels per day oil equivalent) will be $11.0 \mathrm{MMB} / \mathrm{d}$ in 1980 and assuming that all the increase in coal production from $6.2 \mathrm{MMB} / \mathrm{d}$ in the 1971 base period will be used to replace crude oil, our estimate of the self-sufficiency price is $\$ 4.71$.

61. Even for the most inelastic case in Table 3, the self-sufficiency price of $\$ 5.87$ is much lower than the current $\$ 6.63$ wellhead price, indicating substantial potential benefits to consumers of policies aimed at reducing monopoly markups in the domestic oil industry.

62. See "Project Independence Background Paper" (prepared for the Washington Energy Conference, February 1974; processed), pp. 13-14. The Office of Coal of the Federal Energy Administration has since revised its estimates to include three assumptions concerning coal production in 1980: business as usual-892 million tons; business accelerated-1,376 million tons; most likely-950 million tons. The last assumption is similar to the office's initial estimate of 962 million tons of coal per year, which converts to 11.0 million barrels of oil-equivalent a day. 


\section{SUMMARY}

In sum, if the degree of monopoly in the domestic oil industry in 1980 is the same as it was in 1971, and if the government adopts policies that assure that the user cost inherent in crude oil is zero, then the 1980 longrun price for U.S. self-sufficiency will be $\$ 5.36$ (in 1974 dollars) and U.S. production will be $16.9 \mathrm{MMB} / \mathrm{d}$. If imports from friendly nations such as Canada and Venezuela occur in the same proportion to U.S. production as they did in 1971, then the price in 1980 will be $\$ 5.11$. If, on the other hand, coal is increasingly substituted for crude oil, we estimate the 1980 self-sufficiency wellhead price will be $\$ 4.71$. All of these estimates assume our preferred elasticities of supply (1.6) and demand (0.5). Since the January 1974 average wellhead price of domestic crude was $\$ 6.63$, these estimates imply a decrease of between 19.2 percent and 29.0 percent in crude prices in the next few years. In other words, if speculative expectations can be stifled and the degree of monopoly kept at its 1971 level, self-sufficiency can be achieved at lower real costs to the consumers.

Moreover, if monopoly power could be eliminated by antitrust action, government regulation, the formation of a federally sponsored corporation to provide a competitive yardstick, or some combination of the three, then, as Table 3 indicates, the 1980 full self-sufficiency price is most likely to be $\$ 4.11$ - a decline of 38.0 percent from the January 1974 price of crude. Even in the most pessimistic (and unlikely) inelastic case presented in Table 3, the 1980 zero-monopoly price would be $\$ 5.87$, or approximately 11.5 percent less than the 1974 price and only 57.0 percent higher than the base-period price. Thus, any policy that substantially reduces the degree of monopoly in the domestic oil industry could offer dramatic savings to consumers.

Of course, all empirical results assume that domestic production in 1980 involves zero user costs-that producers do not withhold production in order to garner higher profits in the future. This situation may occur fortuitously in 1980 if at that time entrepreneurs' views of the future happen to agree that withholding production is not profitable. On the other hand, such an outcome is by no means inevitable; accordingly, the U.S. government may need specific policies that assure it. These may involve (1) government regulation of wellhead price with the unalterable proviso that permitted price increases must be phased in at an annual rate 
that is lower than current and expected rates of interest (so that discounted profits due to the price increase are negative), or (2) taxes on capital gains on oil reserves and windfall profits on production at rates in excess of 100 percent, or (3) both. ${ }^{63}$ Such policies, operating in tandem with the breaking up of conglomerate energy corporations into independent individual production units advocated in the first half of this paper, will go a long way toward preventing positive user costs and their adverse impact on the production of energy resources at home and abroad.

Finally, and most important, the reader is cautioned that the objective of the second half of this paper has been to provide a range of crude oil prices in 1980. If the U.S. government actively pursues the policies we advocate, we expect the 1980 wellhead price of crude oil in the United States to range between $\$ 5$ and $\$ 7$ (in 1974 dollars) rather than between $\$ 10$ and $\$ 12$, as others have suggested. On the other hand, if the government permits a free market price for oil without altering existing conditions, the 1980 price for self-sufficiency could easily be even higher than $\$ 12$ as the user-cost estimates of domestic producers encourage them to act as willing but silent partners in the OPEC cartel. In that case, domestic oil prices will in essence be set by the sheiks on the Persian Gulf, for we see no reason to believe that the OPEC cartel will unravel of its own accord.

\section{A FINAL CAVEAT}

The $\$ 5.36$ price estimated for the self-sufficiency situation in 1980 involves an increase in annual production of crude oil of more than 75 percent from current levels. Aside from positive user costs, two factors may limit the ability and willingness of the industry to expand by 1980 along the long-run supply path embodying a constant degree of monopoly.

First, the implied increase in exploration activities between 1974 and 1980 may be unachievable at reasonably stable input prices, as bottlenecks develop in the input markets: shortages may occur in drilling rigs, or in the supply of geologist teams, or in the funds necessary for expansion.

In this connection, however, statistics show that the number of shut-in oil-producible zones on the U.S. outer continental shelf jumped from 14.3

63. Other policies could achieve the same objective-government-held buffer stocks that could be dumped if the price begins to rise, for one example. Once the principle of zero user costs is recognized and accepted, economists should be able to conceive of many alternative policies. 
percent of the total completions of producible oil zones in 1971 to 44.4 percent in 1972 and 44.5 percent in $1973,{ }^{64}$ while the number of completed wells continued to grow by some 300 per year from 5,718 in 1971 to 6,421 in 1973. This tremendous increase in readily available, but unused, productive capacity is compatible with the sudden appearance of large positive user costs in 1971 as OPEC actions began to escalate oil prices worldwide. Nevertheless, these shut-ins mean significant additional capacity already in place, and the remaining exploration and development costs necessary to achieve self-sufficiency by 1980 are thus significantly lower (and hence bottlenecks are less threatening) than the inferences of a simple comparison of estimated 1980 output with current production. ${ }^{65}$

Moreover, to the extent that the government alters its leasing policy from front-loaded bonus contracts with fixed-percentage royalty to a bonus system to be paid out of sales revenues (as explained in note 39), financial constraints will be significantly reduced because a major portion of the investment costs (for land) can be financed out of sales receipts.

Second, current (January 1974) prices of $\$ 6.63$ per barrel provide huge windfall profits over long-run marginal factor costs, and hence at least temporarily there has been a tremendous increase in profit markups and therefore in the degree of monopoly since the 1971 base period. If producers (and buyers) come to accept the current higher degree of monopoly as a permanent characteristic of the industry, the relevant long-run supply will shift upwards and the market-clearing self-sufficiency price will be higher and production lower than our preferred estimate. Figure 4 shows, for example, the long-run supply curve $S\left(m_{2}\right)$ for the degree of monopoly in the base period. Here, $D_{0}, D_{c}$, and $D_{n}$ represent the demand curves in the base period, current period, and 1980, respectively; $P_{0}, Q_{0}$, and $P_{n}\left(m_{2}\right), Q_{n}\left(m_{2}\right)$ are the price and production levels for the base period and for 1980 , respectively. The current levels of price and production, which are represented by $P_{c}$ and $Q_{c}$, lie on the short-run, almost vertical, supply curve, $S_{c}$, and on a long-run supply curve, $S\left(m_{3}\right)$, which represents a higher degree of monopoly $\left(m_{3}\right)$ than obtained in the base period. If $m_{3}$ should

64. U.S. Geological Survey, Outer Continental Shelf Statistics (1974), p. 34. In 1965, for example, the ratio of shut-ins was 18 percent, and the trend was steadily downward until 1972.

65. If the United States had such a large percentage of its total productive facilities shut down, does anyone doubt that GNP could be increased by 75 percent by 1980 without severe bottlenecks? 
Figure 4. U.S. Supply and Demand for Crude Oil, Assuming the 1974 Degree of Monopoly Becomes Permanent ${ }^{\mathrm{a}}$

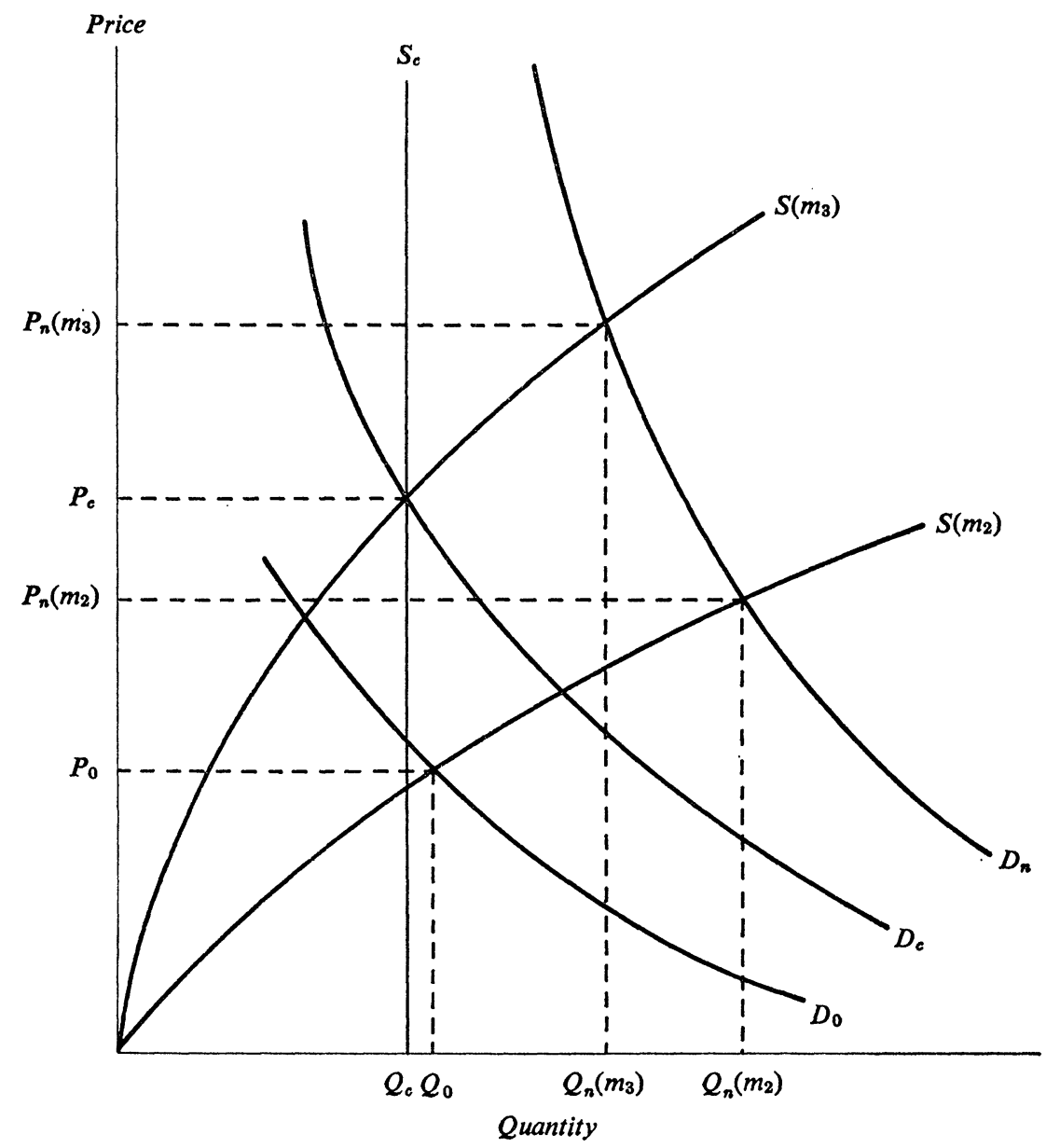

Source: See text for detailed explanation.

a. $m_{2}$ and $m_{3}=$ the 1971 and new, higher, 1974 degrees of monopoly, respectively. Other symbols are as defined for Figure 1.

persist through 1980, then the self-sufficiency price will be $P_{n}\left(m_{3}\right)$-which is higher than $P_{n}\left(m_{2}\right)$-and production will be $Q_{n}\left(m_{3}\right)$-which is lower than $Q_{n}\left(m_{2}\right)$. All of our self-sufficiency estimates are based on the assumption that no disruptive bottlenecks will occur and that monopoly will not intensify. Obviously, if these factors become important as 1980 approaches, 
the government will have to develop policies to counteract them. Merely setting the goal of self-sufficiency, although desirable from the consumer's standpoint in a cartelized world oil market, is not sufficient. The need is for supportive policies to bring prices in line with long-run factor costs by reducing, or at least containing, monopoly power; to discourage inventory speculation by reducing the user cost of crude oil to zero; and to alleviate bottlenecks if they occur. ${ }^{66}$

66. For example, bottlenecks may call for government allocations of scarce resources (at constant factor prices), or redefining self-sufficiency to include imports from friendly nations, or delay in achieving self-sufficiency. Since the current degree of monopoly is higher than historically normal, the government must take steps at least to reduce monopoly power to its former level. 